\title{
PREGNANCY AND ORAL HEALTH
}

\author{
Dr. Mohit Bansal, Dr. Rajesh Kumar Gupta ${ }^{2}$ \\ ${ }^{1}$ Senior Resident, Oral Health Sciences Center, Post Graduate Institute of Medical Education and Research, Chandigarh, (India) \\ ${ }^{2}$ Post graduate student, Department of Periodontology, Bhojia Dental College \& Hospital, Distt. Solan, Himachal Pradesh (India) \\ Corresponding Author: \\ ${ }^{1}$ Mobile- 09855701797, Email: mohit.bansal51@gmail.com
}

\begin{tabular}{|l|}
\hline Received : \\
$12^{\text {th }}$ May, 2013 \\
\\
Accepted: \\
$10^{\text {th }}$ August, 2013 \\
\\
Available online: \\
$25^{\text {th }}$ August, 2013 \\
\hline
\end{tabular}

\section{INTRODUCTION}

It is increasingly recognized that oral health plays an important role in general health and well-being, many women do not visit a dentist before or during pregnancy, even when there are obvious signs of oral disease. ${ }^{1,2}$ A major entryway into the body, the mouth can become a source of disease or pathological processes affecting other parts of the body. Oral health problems are common in pregnant women. Improving the oral health of pregnant women prevents complications of dental diseases during pregnancy. ${ }^{3}$ Recent studies have reported associations between oral diseases, particularly periodontal disease, and an increased risk for poor birth and pregnancy outcomes such as preterm birth, low birth weight. Periodontal disease results in appearance of inflammatory markers in the bloodstream which are also thought to have a role in the onset of labour. ${ }^{1}$

Adaptation to the physiological changes during pregnancy includes dietary changes such as increased craving for particular foods and a higher frequency of snacks between meals. To maintain good oral health during pregnancy, dental care and special home management is required. It is safe to deliver oral health services during the perinatal period, and delaying necessary treatment could result in harm to the mother and indirectly to the fetus. ${ }^{4,5}$

\section{Oral diseases associated with pregnancy}

\section{ABSTRACT}

There is much debate about whether the risk for dental caries is increased in pregnancy. Some changes in caries risk behaviour may occur, but they would need to be substantial and maintained over a long period to have an impact on dental caries rates. Behaviours that may occur and have impact on caries risk are craving for and eating sugary foods and frequent ingestion or use of carbonated drinks to alleviate nausea. ${ }^{6}$

\section{b) Gingival and periodontal disease-}

Gingivitis in pregnancy is caused by bacterial plaque. Pregnancy accentuates the gingival response to plaque and modifies the resultant clinical picture. ${ }^{7}$ These changes may increase susceptibility to oral infections and hinder the body's ability to repair and maintain soft tissues within the mouth. ${ }^{8}$ During pregnancy, reversible mild inflammation of the gums, called "pregnancy gingivitis," is estimated to occur in 30 to 100 percent of pregnant women. ${ }^{9}$ Pregnancy gingivitis usually appears in the first trimester of pregnancy. This form of gingivitis results from increased levels of progesterone and estrogen causing an exaggerated gingival inflammatory reaction to local irritants. ${ }^{10}$

Untreated gingivitis can lead to periodontitis, believed to affect 5 to 20 percent of pregnant women. Periodontitis can erode the bone and other supporting 
structures of teeth resulting in tooth loss. Pyogenic granulomas, pregnancy tumors, or pregnancy epulides occur in $0.2 \%$ to $9.6 \%$ of pregnancies. They are clinically and histologically indistinguishable from pyogenic granulomas occurring in women who are not pregnant or in men. They appear most commonly during the second or third month of pregnancy. The lesion classically occurs in an area of gingivitis and is associated with poor oral hygiene and calculus. ${ }^{11}$

Tooth mobility is a sign of periodontal disease caused by mineral changes in the lamina dura and disturbances in the periodontal ligament attachments. Vitamin $\mathrm{C}$ deficiency contributes to this problem, so the patient should be advised accordingly. Removal of local gingival irritants, therapeutic doses of vitamin $\mathrm{C}$ and delivery typically result in reversal of the tooth mobility. ${ }^{12}$

\section{c) Infection-}

INSTRUCTIONS TO BE FOLLOWED DURING PREGNANCY ${ }^{15}$

\begin{tabular}{|c|c|c|c|c|c|c|}
\hline INDICATIONS & RADIOGRAPHS & $\begin{array}{l}\text { ANALGESICS(with FDA } \\
\text { Category*) }\end{array}$ & $\begin{array}{l}\text { LOCAL } \\
\text { ANESTHETIC (with } \\
\text { FDA Category*) }\end{array}$ & $\begin{array}{l}\text { AMALGAM } \\
\text { PLACEMENT } \\
\text { OR REMOVAL }\end{array}$ & $\begin{array}{l}\text { NITROUS } \\
\text { OXIDE }\end{array}$ & $\begin{array}{l}\text { ANTIBIOTICS \& } \\
\text { ANTI- } \\
\text { INFECTIVES (with } \\
\text { FDA Category*) }\end{array}$ \\
\hline $\begin{array}{l}\text { Anytime during } \\
\text { pregnancy }\end{array}$ & $\begin{array}{l}\begin{array}{l}\text { Diagnostic } x \text {-rays are } \\
\text { safe during } \\
\text { pregnancy }\end{array} \\
\text { Use neck (thyroid } \\
\text { collar) and abdomen } \\
\text { shield }\end{array}$ & $\begin{array}{l}\text { Acetaminophen (B) } \\
\text { Meperidine (B) } \\
\text { Morphine (B) } \\
\text { Codeine (C) } \\
\text { AcetaminophenL+ Codeine } \\
\text { (C) } \\
\text { Acetaminophen } \\
\text { Hydrocodone (C) } \\
\text { Acetaminophen } \\
\text { Oxycodone (C) }\end{array}$ & $\begin{array}{l}\text { Lidocaine with } \\
\text { epinephrine }(2 \%)(\mathrm{B}) \text {, } \\
\text { considered safe during } \\
\text { pregnancy } \\
\text { Mepivacaine }(3 \%)(\mathrm{C}) \text {, } \\
\text { use if benefit } \\
\text { outweighs possible risk } \\
\text { to fetus }\end{array}$ & $\begin{array}{l}\text { No evidence that } \\
\text { the type of } \\
\text { mercury released } \\
\text { from existing } \\
\text { fillings harms the } \\
\text { fetus } \\
\text { Use rubber dam } \\
\text { and high-speed } \\
\text { evacuation to } \\
\text { reduce mercury } \\
\text { vapor inhalation }\end{array}$ & $\begin{array}{l}30 \% \text { nitrous } \\
\text { oxide can be } \\
\text { used when } \\
\text { topical or local } \\
\text { anesthetics are } \\
\text { inadequate } \\
\text { Pregnant women } \\
\text { require lower } \\
\text { levels of nitrous } \\
\text { oxide to achieve } \\
\text { sedation }\end{array}$ & $\begin{array}{l}\text { Penicillin (B) } \\
\text { Amoxicillin (B) } \\
\text { Cephalosporins (B) } \\
\text { Clindamycin (B) } \\
\text { Erythromycin not in } \\
\text { estolate form (B) } \\
\text { Quinolones (C) } \\
\text { Clarithromycin (C) } \\
\text { As prophylaxis for } \\
\text { dental surgery: use } \\
\text { same criteria for all } \\
\text { people at risk for } \\
\text { bacteremia }\end{array}$ \\
\hline $\begin{array}{l}\text { 1st Trimester } \\
(1-13 \text { WEEKS) }\end{array}$ & \multicolumn{5}{|c|}{$\begin{array}{l}\text { Spontaneous pregnancy loss occurs in } 10-15 \% \text { of all clinically-recognized pregnancies in the first trimester. Most losses are } \\
\text { due to chromosome abnormalities. Yet, women may prefer to wait until the second trimester ( } 14^{\text {th }} \text { week) for dental care. }\end{array}$} & $\begin{array}{l}\text { AVOID: } \\
\text { Metronidazole (B) }\end{array}$ \\
\hline $\begin{array}{l}\text { 2nd Trimester } \\
\text { (14-27 WEEKS) }\end{array}$ & & & & & & \\
\hline $\begin{array}{l}\text { 3rd Trimester } \\
(28-40 \text { WEEKS) }\end{array}$ & & $\begin{array}{l}\text { NEVER USE NSAIDs e.g. } \\
\text { Ibuprofen or Indomethacin }\end{array}$ & & & & $\begin{array}{l}\text { AVOID: } \\
\text { Sulfonamides (C) }\end{array}$ \\
\hline $\begin{array}{l}\text { NEVER \& } \\
\text { CAUTIONS }\end{array}$ & & $\begin{array}{l}\text { NEVER USE Aspirin } \\
\text { unless prescribed by the } \\
\text { prenatal care provider } \\
\text { Caution: Consult with } \\
\text { prenatal care provider } \\
\text { before recommending } \\
\text { Ibuprofen (B) or Naprosyn } \\
\text { (B) during the 1st and 2nd } \\
\text { trimesters }\end{array}$ & & & $\begin{array}{l}\text { Caution: } \\
\text { Consult with } \\
\text { prenatal care } \\
\text { provider if using } \\
\text { anesthesia other } \\
\text { than a local } \\
\text { block e.g. IV } \\
\text { sedation or } \\
\text { general } \\
\text { anesthesia }\end{array}$ & $\begin{array}{l}\text { NEVER USE } \\
\text { Tetracyclines (D) } \\
\text { Erythromycin in } \\
\text { estolate form }\end{array}$ \\
\hline
\end{tabular}

\footnotetext{
* Cat B: No evidence of risk in humans; either animal studies show risk (human findings do not) or, if no adequate human studies done, animal findings negative.

* Cat C: Human studies are lacking and animal studies are either positive for fetal risk or lacking as well; potential benefits may justify the potential risk.

* Cat D: Positive evidence of risk. Investigational or post marketing data show risk to fetus. Nevertheless, potential benefits may outweigh the risk.
}

Odontogenic infection during pregnancy have adverse outcomes thus, these should be treated promptly. As such, there is a decrease in cellmediated immunity and natural killer cell activity during infections; hence infections need to be controlled at the earliest. Abscesses should be drained and the offending pulp extirpated or the tooth should be removed to control the infection. ${ }^{10}$

\section{d) Dental Erosion-}

Nausea and vomiting are the commonest symptoms consistently experienced in early pregnancy. Surveys report that nausea with or without vomiting affects about two-thirds of pregnant women, with up to $80 \%$ of these experiencing some nausea, 9.2\% experiencing nausea and vomiting for most of the pregnancy (Louik et al. 2006). ${ }^{13}$ Persistent vomiting may have an erosive effect on tooth structure, and pregnant women should be advised to have a drink of milk or water following a vomiting episode and not to brush their teeth immediately after vomiting. ${ }^{14}$

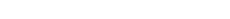




\section{Prevention of oral disease in pregnancy}

Standard preventive measures such as drinking of fluoridated water, twice daily use of fluoridated toothpaste and a low-sugar diet should be recommended for pregnant women (Griffin et al. 2007; Yeung 2007). ${ }^{16}$ Fluoride supplements are not recommended in pregnancy as there is no evidence of effectiveness. A visit to the dentist is recommended for all pregnant women to check on periodontal conditions, as well as to minimise cariogenic oral flora through treatment of existing dental caries and maintenance of oral hygiene habits. Plaque control through meticulous oral hygiene is suggested for minimisation of gingivitis and to reduce the load of oral bacteria. Smoking cessation advice should be part of a preventive strategy for periodontal disease and for the range of conditions with which periodontal disease has been associated. ${ }^{6}$

\section{Dental treatment in pregnancy-}

Other than good plaque control, it is prudent to avoid elective dental care if possible during the first trimester and the last half of the third trimester. The first trimester is the period of organogenesis when the foetus is highly susceptible to environmental influences. In the last half of the third trimester, a hazard of premature delivery exists because the uterus is very sensitive to external stimuli. Prolonged chair time may need to be avoided because the woman is most uncomfortable at this time. Further, supine hypotensive syndrome may possibly occur. Supine hypotensive syndrome can usually be reversed by turning the patient on her left side, thereby removing pressure on the vena cava and allowing blood to return from the lower extremities and pelvic area. A preventive 6-inch soft wedge (rolled towel) should be placed on the patient's right side when she is reclined for clinical treatment. The American academy of Periodontology has developed a position statement regarding the need for proper treatment in pregnant patients. ${ }^{17}$

It is most desirable not to have any irradiation during pregnancy, especially during the first trimester, because the developing foetus is particularly susceptible to radiation damage. When radiographs are needed for diagnosis, the most important aid for the patient is the protective lead apron. Drug therapy in the pregnant patient is controversial because drugs can affect the foetus by diffusion across the placenta. Ideally, no drug should be administered during pregnancy, especially the first trimester. Usually, there is a risk that the drug can enter breast milk and be transferred to the nursing infant, in whom exposure could have adverse effects. The mother should take prescribed drugs just after breastfeeding and then avoid nursing for 4 hours or more, if possible, to markedly decrease the drug concentration in breast milk. ${ }^{7} \mathrm{~A}$ recent clinical trial by Michalowicz et al. $(2008)^{18}$ found that providing dental treatment between 13 and 21 weeks gestation was not associated with any adverse pregnancy outcomes. The treatment provided included scaling and root planning with local anaesthesia, and emergency dental treatment including restorative and surgical care. This supports work by Daniels et al. $(2007)^{19}$ who found that dental care during pregnancy, including amalgam fillings, was not associated with adverse birth outcomes.

\section{Conclusion}

Oral health is very important during pregnancy and can be provided safely and effectively. Dentists need to play a proactive role in the maintenance of the oral health of pregnant women. Regular dental visits are important to diagnose any dental disease at an initial stage. Paying attention to the physiologic changes associated with pregnancy, prescribing medications on the basis of drug safety categories and management of oral infection appropriately are important considerations.

\section{References}

1) Gaffield ML, Gilbert BJ, Malvitz DM, Romaguera R. Oral health during pregnancy: An analysis of information collected by the pregnancy risk assessment monitoring system. Journal of the American Dental Association 2001; 132(7):1009-16.

2) Idaho Department of Health and Welfare. Dental Care during Pregnancy. Idaho Pregnancy Risk Assessment Tracking System.2005 Boise, ID: Idaho Department of Health and Welfare.

3) Xiong X, Buekens P, Fraser WD, Beck J, Offenbacher S. Periodontal disease and adverse outcomes: A systematic review. BJOG: An International Journal of Obstetrics and Gynecology 2006;113(2):135-43.

4) Michalowicz BS, DiAngelis AJ, Novak MJ, Buchanan W, Papapanou PN, Mitchell DA, et al. Examining the safety of dental treatment in pregnant women. Journal of the American Dental Association 2008;139(6):685-95.

5) Kumar J, Samelson R, eds. Oral Health Care during Pregnancy and Early Childhood: Practice Guidelines. Albany, NY: New York State Department of Health. 2006. Available from -http://www.health state.ny.us/publications/ 0824.pdf. 
6) Pregnancy- Oral Health in Pregnancy. Colgate dental education programs a joint program by Colgate Oral Care and The University of Adelaide. 1-2.

7) Newman MG. Takei HH. ,Klokkevold P R., Carrnaza FA. Carranza's Clinical Periodontolgy. 2010.

8) Lopez NJ, Da Silva I, Ipinza J \& Gutierrez J. Higher risk of preterm birth and low birth weight in women with periodontal disease. Journal of Dental Research 2002;81:58 63.

9) Barak S, Oettinger-Barak O, Oettinger M, Machtei EE, Peled M, Ohel G. Common oral manifestation during pregnancy: A review. Obstetrical and Gynecological Survey 2003;58(9):624-8.

10) Giglio JA, Lanni SM, Laskin DM, Giglio NW. Oral Health Care for the Pregnant Patient. JCDA 2009;75(1):43-8.

11) Laine MA. Effect of pregnancy on periodontal and dental health. Acta Odontologica Scandinavica 2002;60(5):257-64.

12) Little JW, Falace DA, Miller CS, Rhodus NL. Dental management of the medically compromised patient. 7th ed. St. Louis: CV Mosby 2008. 268-78.

13) Louik C, Hernandez-Diaz S, Werler MM, Mitchell AA. Nausea and vomiting in pregnancy: maternal characteristics and risk factors. Paediatric and Perinatal Epidemiology 2006;20:270-8.
14) Valena V, YoungWG.Dental erosion patternsfrom intrinsic acid regurgitation and vomiting. Aust Dent J 2002;47:10515

15) Guidelines for Perinatal Care. Available fromhttp://www.acog.org/publications/guidelinesForPerinatalCar e/gpc-83.pdfCopyright October 2007 by the American Academy of Pediatrics and the American College of Obstetricians and Gynecologists. Sixth Edition; 123-4.

16) Griffin, Yeung. Pregnancy part 2 - Widesmile. 2007. Available from- http/- widesmile.co.nz/wp-content/uploads/ 2010/09/pregnancy-part-2.pdf. Assessed on 03/11/12.

17) American Academy of Periodontoly. Statement regarding periodontal management if pregnant patients. J Periodontol 2004;75:495.

18) Michalowicz BS, Diangelis AJ, Novak MJ. Examining the safety of dental treatment in pregnant women. JADA 2008;139(6):685-95.

19) Daniels JL, Andrew S. Rowland AS, Longnecker MP, Crawford P, Golding J. Maternal dental history, child's birth outcome and early cognitive development. Paediatric and Perinatal Epidemiology 2007;21(5):448-57.

Source of Support: Nil, Confilict of Interst: None Declared 